apuntesuniversitarios.upeu.edu.pe

$C C-B Y$

Apuntes Universitarios, 2021: 11(3), julio-setiembre ISSN: 2304-0335 DOI:https://doi.org/10.17162/au.v11i3.699

\title{
Estudio y revisión de la regla de gestión de servicios de problemas y obstáculos en Irán con énfasis en la gestión de recursos humanos
}

\author{
Study and Review of Problems and Obstacles Services Management Rule \\ in Iran with Emphasis on HRM
}

\author{
Shirko Khosravi Nia ${ }^{1 a}$,Farhad Haji Ali Nejad Irani $^{2}$, Gholamreza Rahimi ${ }^{3}$, Seiied \\ Abdollah Hojjati ${ }^{4}$ \\ Department of Public Administration, Bonab Branch, Islamic Azad University, \\ Bonab, Iran ${ }^{1234}$ \\ (iD) ORCID ID: https://orcid.org/0000-0001-6209-34741 \\ (iD) ORCID ID: https://orcid.org/0000-0002-5206-0318 ${ }^{2}$ \\ ORCID ID: https://orcid.org/0000-0003-0877-1806 3 \\ ORCID ID: https://orcid.org/0000-0002-0316-9739
}

Recibido: 19 de noviembre 2020

Aceptado: 26 de marzo de 2021

\begin{abstract}
The objective of this study was to study and review of problems and obstacles services management rule in Iran with emphasis on HRM. Which has been done in a descriptive method of field type and according to the opinion of experts. Statistical samples were selected through quotas. First, an interview was conducted with a statistical sample and then with Delphi method in three stages and exploratory factor analysis. Classifications in the civil service rule are made according to the characteristics of the system in seven categories. The results showed that system deficit, severe bureaucracy and neglect of the environment scored the highest. This factor can be divided into four categories of employment, employment and supply and maintenance of human resources. Ignoring the environment despite extensive communication is another factor. According to the results, it can be said that the civil service management rule in Iran for various reasons such as inflexibility, uncoordinated subsystems, static, lack of dependence and interaction of subsystems, etc. leads to different consequences in the input and output parts of the system in The administrative system of government agencies.
\end{abstract}

Keywords: Problems and Obstacles, Human Resource, Management Rule, Iran

\section{Resumen}

${ }^{\mathrm{a} C}$ Correspondencia al autor:

farhadirani90@yahoo.com 
El objetivo de este estudio fue estudiar y revisar los problemas y obstáculos de la regla de gestión de servicios en Irán con énfasis en la gestión de recursos humanos. Lo cual se ha realizado en un método descriptivo de tipo de campo y según opinión de expertos. Las muestras estadísticas se seleccionaron mediante cuotas. Primero se realizó una entrevista con una muestra estadística y luego con el método Delphi en tres etapas y análisis factorial exploratorio. Las clasificaciones en la regla de la función pública se realizan de acuerdo con las características del sistema en siete categorías. Los resultados mostraron que el déficit del sistema, la burocracia severa y el descuido del medio ambiente obtuvieron los puntajes más altos. Este factor se puede dividir en cuatro categorías de empleo, empleo y oferta y mantenimiento de recursos humanos. Ignorar el medio ambiente a pesar de una amplia comunicación es otro factor. Según los resultados, se puede decir que la regla de gestión de la función pública en Irán por diversas razones como inflexibilidad, subsistemas descoordinados, estática, falta de dependencia e interacción de subsistemas, etc. conduce a diferentes consecuencias en las partes de entrada y salida del sistema en El sistema administrativo de las agencias gubernamentales.

Palabras clave: Problemas y obstáculos, recursos humanos, regla de gestión, Irán

\section{Introduction}

The civil service management rule was approved in 2007 with the aim of solving the problems of the administrative system and was notified to government agencies for implementation. Unfortunately, due diligence has not been shown to implement this rule properly, and now, seven years after its implementation, many of the provisions of this rule have either not been implemented or have been implemented incompletely (Mohammadi et al., 2016).

However, some experts and scholars believe that the formal and substantive defects of the rule and at the same time the incompatibility of its theoretical foundations with the conditions governing the country's administrative system have been among the reasons for the government's failure to implement the rule. In this study, the principles of the subject and the intellectual framework governing the Civil Service Management Rule have been studied and analyzed in the form of three research questions. The results show that in the first and second chapters of the Civil Service Management Rule, issues beyond the administrative system of the country have been addressed, which have been criticized by some experts in this field. Many articles of the rule are based on the principles of modern government management theory and good governance theory, which has been criticized in this regard due to the need to create the necessary conditions for the implementation of these two theories in Iran and the experiences of different countries (Mirsapasi and Qahramani, 2011). 
The foundation of any organization is its human resources and for the success of organizations, the most qualified people should be used in the most suitable job positions (Sham et al., 2018). Organizations are social phenomena that are conscious, coordinated and have a relatively clear boundary with the environment and work continuously to achieve a goal or goals (Arman and Joshaghani, 2015).

In the field of human resources, one of the most important and challenging rules that has been implemented in the Iranand has affected many of the current affairs of the Iranis the "Civil Service Management Rule". This rule in 15 chapters and 128 articles in different chapters with a comprehensive approach to the role, strategies and technology of government duties, organizational structure of agencies, human resources management framework of government agencies, a new model of salaries and benefits of employees, the system of evaluation and management of performance and social security and retirement has been considered (Aminnejad et al., 2015). Considering the various aspects of the issue, including the review of the shortcomings of the previous regulations, the overlap of this rule with the previous regulations, its relationship with the General Policy Implementation Rule of Article 44 of the Constitution (adopted in 2008) in various fields, especially In the field of executive power and also its relationship with the reform of consumption pattern and productivity of human resources, especially how to improve the consumption pattern in the public sector, it is necessary to examine the rule and the principles and principles of each chapter (Ronagh, 2009).

According to the Civil Service Management Rule in the field of human resources, this problem is more apparent; Because now, with the help of knowledge and experience, it has been proven that most of the difficulties of organizations and their managers are directly or indirectly related to manpower issues (Mohammadi et al., 2016). Therefore, the problems and obstacles of the current situation of Iranian government organizations in terms of human resources is of particular importance with the prevailing systemic approach and design of paths to the desired situation in human resources. So, the problems and obstacles process will be complete if it is comprehensive (Bessel and Kim, 2008). Organizational problems and obstacles studies in the first step with various tests, identify the type of disease of the organization and in the next step to treat the disease, strategies and related treatment prescriptions, while creating balance in the system and increasing organizational productivity, Brings positive consequences for society and the organization (Pouras and Berg, 2008). 
The reason for the inadequacy of this approach has been wisely stated by Peter Singe (1998): We have been taught from childhood that problems must be broken, that the world must be crushed. This seems to make it easier to deal with complex issues. But in fact we pay a very high hidden price for it. We will no longer be able to see the sequence of our actions, and we will lose that inner sense of connection to a more comprehensive whole. Although the understanding of the importance of a systems perspective in macro management has been evident from the beginning of the emergence and growth of the field of management, but at the beginning of the new millennium and given events of great historical importance, the importance of a holistic system perspective is emphasized (Castells, 2006). Also, the administrative reform is one of the constant actions of governments around the world (Farazmand, 2001).

In most of the developed countries of the world, governments have made fundamental changes in the structure and re-creation of government in order to deal with the emerging threats and to satisfy as many citizens as possible (Al-Omari and Al-Omari, 2006). Reconstruction means a fundamental change in government systems and organizations in order to increase the efficiency, effectiveness, adaptability and capacity of innovations (Kheirandish et al., 2016). Our Irandoes not need to make these changes; Because the Iranian administrative system has many problems and damages that eliminating them and building a new, dynamic and efficient system requires a review of existing rules and a fundamental review of all existing norms and institutions (Barati et al., 2013). One of the measures taken in this regard is the Civil Service Management Rule. This rule, which was approved in 2007 with the aim of solving the problems of the administrative system, was communicated to the government agencies for implementation. The provisions of this rule have either not been implemented or have been implemented incompletely (Salehi et al., 2018).

If the human resource management system is not properly designed, managers and employees in this field are not carefully selected and obsessively selected, or at least will not keep pace with the needs of the day. Because the recruitment of appropriate manpower is only part of the human resource management system and the other part is to maintain the quality of manpower and develop their capabilities, which is done in the form of training programs. Also, if a proper evaluation system is not designed, so that there is no difference between good and bad performance, naturally the motivation for useful activities and valuable efforts in people decreases and manpower goes into recession and daily life. Giurian and Rabiee (2002) have written in this regard how many policies are made and compiled at different levels and positions of policy- 
making and legislation. But when they are in the implementation stage, they do not have the necessary efficiency and effectiveness and face obstacles and problems. Another problem with the way policies is implemented is the lack of a generalist idea. When policy makers or decision makers pay attention to one aspect of the issue and neglect the other aspects, incomplete results will be obtained in practice (Dana Esfahani and Taherpour, 2012). Therefore, the objective of this study was study and review of problems and obstacles services management rule in Iran with emphasis on HRM.

\section{Methodology}

Research methodology in administrative sciences, government organizations and management is one of the important topics. In research management, areas such as the attitude and behavior of human resource management staff include the impact of demographic characteristics on management operations, production operations management, information systems strategy formulation, and so on (Barati et al., 2013).

Considering that the present study is the study and review of problems and obstacles services management rule in Iran. It ultimately leads to a practical model, a fundamental research. In this research, to eliminate the shortcomings in previous research, it uses a qualitative approach (Aminnejad et al., 2015). Therefore, its multifaceted, comprehensive approach is covered in this way and also according to various considerations by experts at the level of the country's employment organization, the country's administrative education organization, Iran University of Medical Sciences, the country's management and planning organization and the social office of the Islamic Consultative Assembly (Maliki et al., 2016).

According to the causal conditions, context and intervener, in addition to internal variables, external and environmental variables have also been considered. In fact, this study seeks to address the study and review of human resource services management rule in its true context. One of the different types of qualitative research strategies is the theoretical method derived from data, which has been considered in this research due to some of its special features (Mirsapasi and Qahramani, 2011).

For the study and review of human resource services management rule in this research through in-depth interviews related to data theory, the statistical population includes officials of the Employment Organization, Administrative Education Organization, Iran University of 
Medical Sciences, Management and Planning Organization and the Social Office of the Islamic Consultative Assembly (Aminnejad et al., 2015).

In this research, a combination of purposeful judgment methods and snowball method has been used to select the sample, which is a non-probabilistic method (Castells, 2006). In this method, the work was started by people who were experts in this field and had the necessary criteria, and in addition to research questions, they were asked to introduce other experts in this field. Therefore, except for the first few people who were directly selected by the researcher based on the desired criteria. Other experts have been selected by other experts in addition to the expertise criteria (Farazmand, 2001). On the other hand, the adequacy of sampling is achieved by theoretical sampling method. In this method, sampling continues until the researcher has the most information about the subject of research and knowledge of the phenomenon. In doing this, they use methods that require simultaneous selection and sequential selection of data and their analysis.

\section{Results}

As explained in the previous section, i. e. in the research method. In order to review the research results, the opinions of experts have been used and the results of the studies and comments are presented in the following tables. In each section, special topics are discussed and the results are given in tables and discussed.

Table 1

Results of the holistic feature of the human resources system

\begin{tabular}{cccc}
\hline Features & Concept & Criteria & Code \\
\hline & Current & Recruitment system & CE8 \\
& situation & Recruitment system & CE24 \\
& & Supply system & CE16 \\
& & Human resource maintenance system & CE37 \\
& & Education system & CE41 \\
& harm & Lack of immune system & ST3 \\
& & Lack of health system & ST67 \\
& & Lack of competency system & ST8 \\
& & Strict bureaucracy to respond to the & ST86 \\
& & client & \\
& & Ignore the environment despite & \\
& & extensive communication & \\
\hline
\end{tabular}


Table 2

Results of the characteristics of inconsistency and coordination of the human resources system

\begin{tabular}{|c|c|c|c|}
\hline feature & concept & index & code \\
\hline \multirow{8}{*}{$\begin{array}{l}\text { Consistency } \\
\text { and } \\
\text { inconsistency }\end{array}$} & Harm & Do not outsource administrative affairs & MT3 \\
\hline & $\begin{array}{l}\text { (Inconsistency between } \\
\text { the Department of }\end{array}$ & $\begin{array}{l}\text { Lack of performance-based payment } \\
\text { system }\end{array}$ & MT5 \\
\hline & $\begin{array}{l}\text { Public Affairs and the } \\
\text { field of human }\end{array}$ & $\begin{array}{l}\text { Lack of transparency of central justice } \\
\text { in the system of attraction }\end{array}$ & MT18 \\
\hline & resources) & Lack of delegation to managers in the & MT21 \\
\hline & & field of recruitment & \\
\hline & & $\begin{array}{l}\text { Lack of incentive incentives to provide } \\
\text { services to qualified people }\end{array}$ & MT29 \\
\hline & $\begin{array}{l}\text { Current situation } \\
\text { (Coordination between }\end{array}$ & $\begin{array}{l}\text { Career promotion based on the } \\
\text { educational system }\end{array}$ & MS5 \\
\hline & $\begin{array}{l}\text { the Department of } \\
\text { Public Affairs and the } \\
\text { field of human } \\
\text { resources) }\end{array}$ & $\begin{array}{l}\text { In line with payment with the education } \\
\text { system }\end{array}$ & MT11 \\
\hline
\end{tabular}

The other question asked of the participants in the interview was "What are the disadvantages of the Civil Service Management Rule with emphasis on the nature of interdependence and interaction between system components (principle of combined thinking) in the field of human resource management in Iranian government organizations?” In response to this question and based on the participants' point of view, interaction and non-interaction between the components is observed.

\section{Dependence and interaction between system components (principle of hybrid thinking)}

One of the disadvantages of the Civil Service Rule is the lack of attention to detail, which has led to the interaction and dependence between the components of the system. The lack of a schematic and unified picture of the implementation processes of the Civil Service Rule in the field of human resources with the slightest changes confuses people, which has led people to make decisions based on experience. Government officials believe that the interaction of the components does not lead to synergy, but has caused many problems. 
Table 3

Results of the nature of dependence and interaction between components of human resource systems

\begin{tabular}{|c|c|c|c|}
\hline feature & concept & index & code \\
\hline \multirow{9}{*}{ 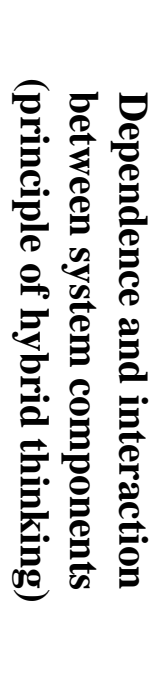 } & Harm & Managers' mental perception of the concepts & KT4 \\
\hline & & of civil service such as retirement & \\
\hline & $\begin{array}{l}\text { dependence and } \\
\text { interaction between }\end{array}$ & $\begin{array}{l}\text { Lack of schematic and single image of the } \\
\text { executive processes of the Civil Service Rule }\end{array}$ & KT6 \\
\hline & components) & Do not anticipate changes & KT14 \\
\hline & & Individual experiences in the face of change & KT13 \\
\hline & & $\begin{array}{l}\text { Lack of maintenance of capable people due to } \\
\text { the weakness of the compensation system }\end{array}$ & KT15 \\
\hline & & Restrictions and simplifications throughout the & KT24 \\
\hline & Current situation & Interaction between system components & KM8 \\
\hline & $\begin{array}{l}\text { (Dependence and } \\
\text { interaction between } \\
\text { components) }\end{array}$ & through board decisions & \\
\hline
\end{tabular}

The other question asked of the participants in the interview was "What are the disadvantages of the Civil Service Management Rule with its emphasis on getting feedback on the performance of system components in the areas of human resource management in the Iranian government organization?" In response to this question and based on the view of the participants, there is no feedback on the performance of the system to amend the Civil Service Management Rule.

\section{Pay attention to dynamic system processes (instead of static processes)}

All the officials of the governmental organizations unanimously believe that the processes of the system are static, which are due to the modeling of developed countries and do not pay attention to the work environment and the characteristics of the employed person. Therefore, in most of the topics, the generalities are addressed and the uniformity of job description is considered in the same way for all organizations, regardless of the specialization and working hours and the type of work of the individual. Therefore, the processes of the human resources system are completely static and uniform, which has created many problems due to this feature. 
Table 4

Characteristic Results Paying attention to the dynamic processes of human resource systems

\begin{tabular}{|c|c|c|c|}
\hline Features & concepts & indexes & codes \\
\hline \multirow{9}{*}{ 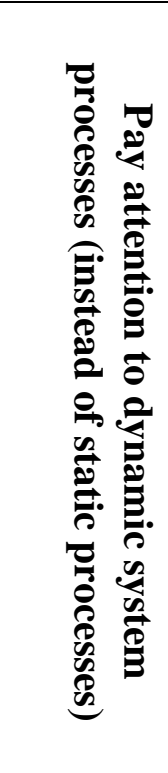 } & \multirow{7}{*}{$\begin{array}{c}\text { Harm } \\
\text { (Weaknesses of } \\
\text { static } \\
\text { processes) }\end{array}$} & The entry of unworthy people through & AC1 \\
\hline & & the weakness of the service rule & \\
\hline & & $\begin{array}{l}\text { Rule enforcement perception based on } \\
\text { personal interests and resources }\end{array}$ & AC9 \\
\hline & & $\begin{array}{l}\text { Uniformity of job descriptions for all } \\
\text { government organizations }\end{array}$ & AC15 \\
\hline & & $\begin{array}{l}\text { Modeling processes from developed } \\
\text { countries regardless of Iran's } \\
\text { environmental conditions }\end{array}$ & AC19 \\
\hline & & $\begin{array}{c}\text { Finality of the rule regardless of the } \\
\text { time }\end{array}$ & AC23 \\
\hline & & Inflexibility & AC25 \\
\hline & \multirow{2}{*}{$\begin{array}{l}\text { Current } \\
\text { situation } \\
\text { (Dynamic } \\
\text { solutions) }\end{array}$} & System Dynamics Tool Regulations & AM3 \\
\hline & & $\begin{array}{c}\text { Digital technologies as quasi-dynamic } \\
\text { structures }\end{array}$ & AM6 \\
\hline
\end{tabular}

The other question asked of the participants in the interview was "What are the disadvantages of the Civil Service Management Rule with emphasis on the nature of the system's environmental relationship in the areas of human resource management in Iranian government organizations?” In the previous question, it was stated that the human resources system does not have dynamism and interaction; which has also affected the nature of environmental communication. Officials of government organizations have addressed the issue from the perspective of customer service, the perspective of underlying factors, internal and external labor force, adaptability or non-adaptability, and the perspective of conflict of delegation to organizations in relation to the environment.

Table 5

Results of environmental communication characteristics of human resource systems 


\begin{tabular}{|c|c|c|c|}
\hline $\begin{array}{l}\text { Featu } \\
\text { res }\end{array}$ & concepts & Indexes & code \\
\hline \multirow{19}{*}{ 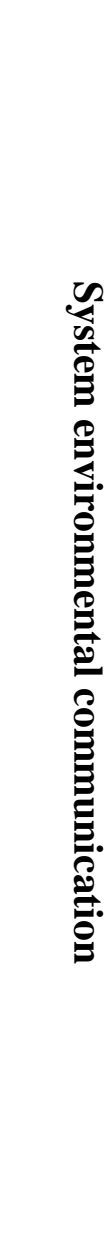 } & $\begin{array}{l}\text { Customer } \\
\text { service }\end{array}$ & $\begin{array}{c}\text { Not helping to improve the country's business } \\
\text { environment }\end{array}$ & EC5 \\
\hline & perspective & $\begin{array}{c}\text { Lack of proper regulations for labor market } \\
\text { preparation }\end{array}$ & EC8 \\
\hline & \multirow{8}{*}{$\begin{array}{c}\text { Perspectives } \\
\text { of contextual } \\
\text { factors }\end{array}$} & Lack of proper implementation of labor market & EC1 \\
\hline & & training rule & 3 \\
\hline & & Non-compliance of labor market training & EC1 \\
\hline & & regulations with the Civil Service Rule & 5 \\
\hline & & Lack of attention to a worthy performer & EC1 \\
\hline & & f comnetition with the private sector in the & $\begin{array}{c}8 \\
\text { FC1 }\end{array}$ \\
\hline & & Civil Service Rule & $\begin{array}{l}\text { ECI } \\
9\end{array}$ \\
\hline & & Lack of proper maintenance tools & $\begin{array}{c}\text { EC2 } \\
3\end{array}$ \\
\hline & Internal and & High labor demand to enter foreign markets & $\begin{array}{c}\text { EC2 } \\
8\end{array}$ \\
\hline & force & Reduction of qualified forces & EC3 \\
\hline & & & 1 \\
\hline & Adaptability & Lack of willingness of employees to improve & EC3 \\
\hline & or non- & knowledge and skills & 2 \\
\hline & adaptability & Rule enforcement regardless of individual merit & $\begin{array}{c}\text { EC3 } \\
6\end{array}$ \\
\hline & $\begin{array}{l}\text { Conflict view } \\
\text { of delegating }\end{array}$ & Assign tasks from one organization to another & $\begin{array}{c}\text { EC3 } \\
8\end{array}$ \\
\hline & tasks to & Ambiguity in performing tasks due to the & EC4 \\
\hline & organizations & presence of multiple executors & 1 \\
\hline
\end{tabular}

The other questions asked to the participants in the interview were: "What are the disadvantages of the Civil Service Management Rule with emphasis on the characteristics of inputs (outputs) and outputs (outputs) of the system in the field of human resource management in Iranian government organizations?”

Table 6

Characteristics results of inputs and outputs of human resource systems

\begin{tabular}{cccc}
\hline features & concepts & indexes & code \\
\hline & Harms of & Lack of decent manpower & IN5 \\
& system & Central taste in hiring & IN8 \\
inputs & Inability to retain manpower & IN12 \\
Non-payment of wages based on & IN16 \\
& & performance &
\end{tabular}


Lack of job and job characteristics IN18

Harms of Rising unemployment in the community OU6

system Poor job performance OU8

outputs Inefficiency due to inefficiency of the OU9

system

Lack of attractiveness for retirement $\quad$ OU11

Job dissatisfaction OU16

Inefficiency and productivity of the OU18

human resources system

Not delegating authority to managers $\quad$ OU21

Lack of specific upgrade processes $\quad$ OU23

After determining the final list of violations of the Civil Service Rule, managers of government agencies and experts were asked to comment on the effectiveness of each of the identified components in identifying injuries based on a systemic approach based on the five Likert scale.

In this study, Kendall coordination coefficient was used to determine the degree of consensus among panel members. This comparative coefficient is used to determine the degree of coordination and agreement of several ranks related to $\mathrm{N}$ object or person. The value of this scale is between 0 and 1. 9 members of Delphi panel have completed the questionnaire. Finally, Kendall's coordination coefficient has improved significantly after three periods.

Table 7

Calculation of Kendall coefficient for statistical results in the first to third stage of Delphi

\begin{tabular}{ccccccc}
\hline Items & \multicolumn{2}{c}{ First period } & \multicolumn{2}{c}{ Second period } & \multicolumn{2}{c}{ Third period } \\
& number & $\begin{array}{c}\text { Kendal } \\
\text { coefficient }\end{array}$ & number & $\begin{array}{c}\text { Kendal } \\
\text { coefficient }\end{array}$ & number & $\begin{array}{c}\text { Kendal } \\
\text { coefficient }\end{array}$ \\
\hline $\begin{array}{c}\text { Injuries related to } \\
\text { generalization }\end{array}$ & 9 & 0.43 & 9 & 0.51 & 9 & 0.67 \\
$\begin{array}{c}\text { Disorders related } \\
\text { injuries }\end{array}$ & 9 & 0.50 & 9 & 0.5 & 9 & 0.68 \\
$\begin{array}{c}\text { Injuries related to } \\
\text { coordination }\end{array}$ & 9 & 0.61 & 9 & 0.73 & 9 & 0.75 \\
$\begin{array}{c}\text { Damages related to } \\
\text { the rule enforcement } \\
\text { environment }\end{array}$ & 9 & 0.50 & 9 & 0.54 & 9 & 0.68 \\
\end{tabular}


Injuries related to domestic and foreign labor

Adaptability or nonadaptability

Incoherence

Damages related to dynamic processes

Feedback on the performance of system components Damages related to the lack of interdependence between components

Injuries related to input properties

Damages related to the properties of the outputs

$\begin{array}{llllll}9 & 0.71 & 9 & 0.73 & 9 & 0.80 \\ 9 & 0.53 & 9 & 0.64 & 9 & 0.73 \\ 9 & 0.61 & 9 & 0.72 & 9 & 0.76 \\ 9 & 0.53 & 9 & 0.64 & 9 & 0.67 \\ 9 & 0.52 & 9 & 0.61 & 9 & 0.67 \\ 9 & 0.63 & 9 & 0.65 & 9 & 0.69 \\ 9 & & & & & \\ 9 & 0.65 & 9 & 0.63 & 9 & 0.74 \\ 9 & 0.62 & 9 & 0.73 & 9 & 0.77\end{array}$

Investigating the results of violations of the Civil Service Management Rule in the field of human resources based on the characteristics of the systemic attitude resulting from exploratory factor analysis.

\begin{tabular}{|c|c|}
\hline $\begin{array}{l}\text { Features of general view } \\
\text { - Lack of safe system } \\
\text { - Lack of healthy system } \\
\text { - Lack of meritocracy system } \\
\text { - } \\
\quad \text { Severe Bureaucracy to } \\
\text { customer response }\end{array}$ & $\begin{array}{l}\text { Features of coordination and inconsistency } \\
\text { Inconsistency } \\
\text { - Do not outsource administrative affairs } \\
\text { - Lack of performance-based payment system } \\
\text { - Lack of transparency of central justice in the } \\
\text { employment system } \\
\text { - Lack of motivational incentives to compensate } \\
\text { for deserving people } \\
\text { Coordination } \\
\text { - Career promotion based on the educational } \\
\text { - } \text { system } \\
\text { Alignment of payment with the educational } \\
\text { system }\end{array}$ \\
\hline
\end{tabular}




\begin{tabular}{|c|c|}
\hline $\begin{array}{l}\text { Features of environmental } \\
\text { communication of system } \\
\text { Customer service delivery } \\
\text { viewpoint } \\
\text { - Not helping to improve the } \\
\text { business environment } \\
\text { - Lack of proper regulations } \\
\text { for preparing the labor } \\
\text { market } \\
\text { Lack of proper } \\
\text { implementation of labor } \\
\text { rule training rule } \\
\text { Non-compliance of labor } \\
\text { market training regulations } \\
\text { with the Iranian Civil } \\
\text { Service Rule }\end{array}$ & $\begin{array}{l}\text { Perspectives on environmental rule enforcement } \\
\text { factors } \\
\text { - Lack of attention to a worthy performer } \\
\text { - } \quad \text { Lack of competitiveness with the private } \\
\text { Internal and external labor force } \\
\text { - High labor demand to enter the labor market } \\
\text { - Reduction of qualified forces } \\
\text { Adaptability or non-adaptability } \\
\text { - Unwillingness of employees to improve skills } \\
\text { Rule enforcement regardless of individual merit } \\
\text { Lack of coherence in the tasks of organizations } \\
\text { - Assigning the tasks of one organization to } \\
\text { another } \\
\text { Ambiguity in performing tasks due to the presence of } \\
\text { multiple executors }\end{array}$ \\
\hline
\end{tabular}

Figure 1

Violations of the Civil Service Rule in the field of human resources based on the characteristics of the systemic approach

\section{Discussion}

This research, like other studies and researches, is not without limitations. One of the main limitations of the present study was the scope of the civil service rule. Although government agencies have used the civil service rule in the field of human resources, they have had many interpretations of the rule. Therefore, the researcher had to integrate the scattered information in different fields in a relatively long process for analysis. Another limitation of the study was the large number of injuries, which led to the collection and classification over a period of 6 months. Also, values, perceptions, mentalities, perceptions, interests, knowledge and characteristics and knowledge of the researcher and other personal characteristics such as the ability to interact with others, etc. in choosing open source, categories, question design, questionnaire, communication with others and work analysis Lays. This research is not safe from these effects and naturally, the characteristics, knowledge and interests of the researcher have also affected this research, which should be considered as one of the limitations of the research. 
The objective of this study was to study and review of problems and obstacles services management rule in Iran with emphasis on HRM. The results show that: The first question asked of the participants in the interview was "What are the disadvantages of the Civil Service Management Rule with emphasis on the nature of coordination between system components (principle of non-conflict) in the field of human resource management in Iranian government organizations?” In response to this question, and from the point of view of the participants, there is a clear discrepancy between the rule on public administration and the field of human resources.

One of the weaknesses of the Civil Service Management Rule is the inconsistency between the components of the system. Thus, before the adoption of the management rule in the country, there was a national employment rule, and after that, the payment system was created, with the greatest focus on the payment system. Civil Service Management Rule in two parts, the first part of which is the Rule on Public Administration and the other part is the field of human resources. The main idea of the formation of the country's management rule has been influenced by the word modern government management. In its content, there are roots of assignments, privatizations, etc., which form the keywords of the first two chapters. In the field of human resource management, there is no coordination between these two main parts. If we want to act on the basis of modern government management. We have to give the authority to the managers and they manage it and ask them to respond, including the authority to recruit and provide services to the manager. Because we want to dominate management. Another disadvantage is the lack of coordination between the service compensation system and the competency system. Service compensation is not defined for qualified individuals. One of the harms of civil service rule is ignoring knowledge management in civil service rule. The issues raised in recruitment and employment are consistent with the researches of Rostami (2010), Purkiani et al. (2014), Mohammadi et al. (2015) and Najabatkhah and Larijani (2015).

The other question asked of the participants in the interview was "What are the disadvantages of the Civil Service Management Rule with emphasis on the nature of interdependence and interaction between system components (principle of combined thinking) in the field of human resource management in Iranian government organizations?" In response to this question and based on the participants' point of view, interaction and non-interaction between the components is observed. 
One of the disadvantages of the Civil Service Rule is the lack of attention to detail, which has led to the interaction and dependence between the components of the system. The lack of a schematic and unified picture of the implementation processes of the Civil Service Rule in the field of human resources with the slightest changes confuses people, which has led people to make decisions based on experience. Government officials believe that the interaction of the components does not lead to synergy, but has caused many problems. The issues raised in the maintenance section are consistent with the researches of Azar and Latifi (2008), Harisinejad et al. (2017) and Salehi et al. (2015).

The other question asked of the participants in the interview was "What are the disadvantages of the Civil Service Management Rule with its emphasis on getting feedback on the performance of system components in the areas of human resource management in the Iranian government organization?" In response to this question and based on the view of the participants, there is no feedback on the performance of the system to amend the Civil Service Management Rule.

Each organization has defined different indicators to measure the performance of human resources. Based on performance points, rewards are considered for employees. However, the performance of human resources can be attributed to the performance of the Civil Service Rule, which is not provided for in the Civil Service Rule. Also, fundamental review of the rule, lack of a clear regulatory system, failure to determine evaluation criteria in the implementation of the rule, failure to determine regulatory authorities, lack of commitment of rule enforcement officials, selfinterest of employees and lack of mental discipline in enforcement are the main reasons for feedback.

The other question asked of the participants in the interview was "What are the disadvantages of the Civil Service Management Rule with emphasis on paying attention to dynamic system processes (instead of static processes) in the field of human resource management in Iranian government organizations?" In response to this question and based on the participants' views, they expressed the weaknesses of static processes and dynamic system solutions.

All the officials of the governmental organizations unanimously believe that the processes of the system are static, which are due to the modeling of developed countries and do not pay attention to the work environment and the characteristics of the employed person. Therefore, in most of the topics, the generalities are addressed and the uniformity of job description is considered 
in the same way for all organizations, regardless of the specialization and working hours and the type of work of the individual. Therefore, the processes of the human resources system are completely static and uniform, which has created many problems due to this feature.

Issues and problems of the Civil Service Rule in the performance appraisal section include lack of comprehensive reporting of internal issues and problems of organizations and lack of action plans by government organizations, weakness in individual performance management, lack of motivation indicators, lack of functional skills development program, lack of attention According to the criteria of the executive roadmap for transformation in the administrative system, according to the requirements of the executive body in evaluating the performance of employees, lack of logical relationship between organizational strategy and human capital strategy, not considering the level of accountability and responsibility, taking into account individual characteristics of employees in evaluations.

Rewards and punishments and not paying attention to the issue of education and empowerment system of government employees, along with paying attention to the maturity of the knowledge management system, lack of indicators for measuring intelligence (logical intelligence, emotional intelligence, cultural intelligence and spiritual intelligence), lack of preparation and route planning Career advancement, lack of assessment of the suitability of the candidates for management positions with managerial positions, lack of simulated tests to measure the readiness and ability to make decisions are important conditions that the issues raised in the performance appraisal section with The researches of Barati et al. (2013), Attarian et al. (2016) and Mohammadi and Sharifzadeh (2017) are consistent.

The other question asked of the participants in the interview was "What are the disadvantages of the Civil Service Management Rule with emphasis on the nature of the system's environmental relationship in the areas of human resource management in Iranian government organizations?" In the previous question, it was stated that the human resources system does not have dynamism and interaction; which has also affected the nature of environmental communication. Officials of government organizations have addressed the issue from the perspective of customer service, the perspective of underlying factors, internal and external labor force, adaptability or non-adaptability, and the perspective of conflict of delegation to organizations in relation to the environment. 
The other questions asked to the participants in the interview were: "What are the disadvantages of the Civil Service Management Rule with emphasis on the characteristics of inputs (outputs) and outputs (outputs) of the system in the field of human resource management in Iranian government organizations?"

Issues and problems of the Civil Service Rule in the field of empowerment include onesidedness of the staff training system index as empowerment and not paying attention to other indicators of staff empowerment, not paying attention to two dimensions of individual and organization in empowerment, not paying attention to the personality-job fit index Career path is paying attention to general and general skills and not measuring job-related skills, not considering the risk index in employee empowerment, not considering the responsibility index in employee empowerment and not caring about the impact of higher education on future employee empowerment; The issues raised in the empowerment section are consistent with the researches of Attarian et al. (2016) and Salehi et al. (2015).

Issues and problems of the Civil Service Rule in the field of salaries and benefits include the interpretation of the rule by individuals and different interpretations of salaries and benefits, unfamiliarity of employees in the discussion of payment rule, ambiguity of implementation and answering questions and protests of employees. Lack of byrules, mechanisms and executive instructions of salaries and benefits that are required for the implementation of this rule 55 byrules, irregular payment of wages, difference in payments between different occupational groups despite the same conditions, discrimination in the interpretation of payroll and benefits by managers, inadequacy Increase of salaries with inflation rate and cost of living index, creation of legal gap between retirees, non-observance of the rule of coordinated system of payment of salaries of government employees, decrease of purchasing power of retirees and pensioners, dissatisfaction of retirees and pensioners of the Armed Forces; The issues raised in the benefits rule section are consistent with the research of Barati et al. (2013), Mohammadi et al. (2016), Najabatkhah and Larijani (2016) and Shahlaei (2017).

Issues and problems of the Civil Service Rule The information and communication technology systems have not been used well, and this has led to problems such as the lack of integration of services provided to the people, improvement through Internet portals, the existence of paperwork and long processes in providing services, the existence of information. Accurate and sufficient to make the right decision include lack of training in the use of government services, 
limiting the provision of services to a certain level due to lack of infrastructure; Which is consistent with the research of Khairandish et al. (2016).

The input of the human resource management system includes recruiting, meriting people, retaining human capital and compensating for services. The output of the human resources system is related to job performance and the pension system. Thus, the Civil Service Management Rule for various reasons such as inflexibility, uncoordinated subsystems, static, non-dependence and interaction of the subsystem, etc. has led to various consequences in the input and output parts of the system. Consequences of entering the system include lack of recruitment of qualified manpower, central taste in employment, inability to retain manpower, non-payment of wages based on performance and lack of job and job characteristics. Also, the consequences of the system output include increasing the unemployment rate of the society, poor job performance, inefficiency due to inefficiency of the system, lack of attractiveness for retirement, job dissatisfaction, inefficiency and productivity of the human resources system, lack of delegation to managers, lack of specific promotion processes.

\section{Conclusion}

According to the results we can say that due to the lack of technology such as virtual cloud hosts, online video, web analyst in Iran, in future research, human resources systems with emphasis on information technology systems such as employment awareness, systems-based training, Performance evaluation system based on management dashboards, awareness of upgrading and updating instructions, employee participation in social networks to raise the violations of the Civil Service Rule and launching a suggestion system, analysis of employee behaviors including entry and exit based on artificial intelligence, should also be considered.

Also, the existence of ambiguity in the implementation of the rule is one of the problems in the field of implementation, while the legal texts should be clear, transparent and transparent so that the executors do not have doubts and ambiguities in the implementation and from different interpretations and Avoid with tasteful interpretations. It is suggested that the transparency of the rule be addressed by using the approved regulations of the decisions of the Board of Trustees. It is necessary for future researchers to be aware of the regulations before the interview and the questionnaire. 


\section{References}

Adel, A., Latifi, M. (2008). Revenue on process requirements and criteria for selecting government human resource managers. Management Thought, 2(2), 37-69. http://smt.journals.isu.ac.ir/article_116.html

Al-Omari, A., \& Al-Omari, H. (2006). E-Government Readiness Assessment Model. Journal of Computer Science, 2(11), 841-845. 10.3844/jcssp.2006.841.845

Aminnejad, K., Memarzadeh, G., \& Mobini, M. (2015). Investigating the effectiveness of training courses in employee empowerment, subject to Article 58 of the Civil Service Management Rule (Case study: Road, Housing and Urban Development Research Center). Journal of Development and Transformation Management, 21, 23-33. http://www.jdem.ir/article_466_3989d1aebc2d2a335890651583e45622.pdf

Arman, M., \& Joshaghani, H. (2015). Designing and validating a model for analyzing the status of the human resource management system. Quarterly Journal of Human Resources Management Research, 7(4), 71-94. https://hrmj.ihu.ac.ir/article_18675.html

Attarian, F., Mirsapasi, N., \& Musikhani, M. (2016). Problems and obstacles of amending the Civil Service Management Rule with the approach of empowering the employees of government executive bodies. Quarterly Journal of Public Management Mission, 7, (22), 1-16. http://ijpa.srbiau.ac.ir/article_9591.html

Bissel, BL., \& keim, J. (2008). Organizational diagnosis: The role of contagion groups. The International Journal of Organizational Analysis, 16(2), 7-15. https://phad.ph.mahidol.ac.th/research/2558/149_Surachart.pdf

Brown, D.R., Harvey, D. (1988). "An Experiential Approach to Organization Development", Upper Saddle River, NJ: Pearson Prentice Hall. http://www.hrd-forum.com/wpcontent/uploads/2018/05/Organizational-Development-ebook.pdf

Castells, M. (2006). Information Age: Economy, Society and Culture (The Rise of a Network Society), Translated by Ahad Aliqlian and Afshin Khakbaz, Tarh-e No Publications, Tehran, Fifth Edition. http://www.ipcsit.com/vol27/41-ICICN2012-N20009.pdf

Dana Isfahani, Z., \& Taherpour, H. (2012). Identifying the effective factors on the implementation of Chapter 9 of the Civil Service Management Rule (Employee Empowerment) in government organizations, Quarterly Journal of Development and Transformation Management, 4(11), 33-49. https://www.sid.ir/Fa/Journal/ViewPaper.aspx?ID=218793 
Farazmand, A. (2001). Administrative Reform in Developing Nations. 1st Edition, London: Praeger Publishing. https://www.gisoom.com/book/1301750

Forouzandeh Dehkordi, L. (2008). Investigating the role of new management theories in the Civil Service Management Rule. Tomorrow Management Magazine, 7(19), 21-33. https://www.sid.ir/fa/journal/ViewPaper.aspx?ID=161961

Gharajedaghi, J. (2011). Systems thinking: managing chaos and complexity: a platform for designing business architecture (3rd ed.). Burlington, MA: Morgan Kaufmann. https://www.gisoom.com/book/11218144

Giurian, H., \& Rabiee, M. (2002). Decision Making and Determining Government Policy, Yakan Publications: Tehran. https://www.gisoom.com/book/1857601

Hadavand, M., \& Kazemi, D. (2013). A reflection on the modern principles of administrative rule in the Civil Service Management Rule. Strategy Quarterly, 22(67), 127-140. http://tahavol.saminatech.ir/WebUsers/tahavol/Journals/jfilep5637126941132101956.pdf

Hall Mark, L., Cynthia, A., Lengnick-Hall, Leticia, S. Andrade \& Brian Drake (2009). Strategic human resource management: The evolution of the field, Human Resource Management Review, 19, 64-85. https:/www.sjsu.edu/people/stan.malos/docs/251\%20LengnickHall\%201.pdf

Harisinejad, K., Jangjo, Farzad., \& Lotfi, A.(2014). An analysis of the probationary period of employment in the Civil Service Management Rule. Administrative Rule Quarterly, 1(4), 89-112. http://qjal.smtc.ac.ir/article-1-43-fa.html

Howard, A. (2004). Diagnosis for Organizational Change: Methods and Models. New York, NY: The Guilford Press. https://catalogue.nla.gov.au/Record/1834414

Kheirandish, M., Hasanpour, A., \& Falahzavareh, M. (2013). Problems and obstacles of the service compensation system with emphasis on the Civil Service Management Rule. Human Resources Quarterly, 2(7), 78-99. https://elmnet.ir/article/1010594-89311

Kheirandish, M., Shakeri, Gh., \& Ghanizadeh, A.(2016). Problems and obstacles of the effectiveness of the use of information technology and administrative services in the Civil Service Management Rule. Quarterly Journal of Management of Government Organizations, 3(14), 56-77. http://ipom.journals.pnu.ac.ir/ 
Kolb, D. A. \& Frohman, A. L. (2012). An Organization Development Approach to Consulting. Sloan Management Review, 12, 51-65. https://learningfromexperience.com/about/DavidKolb-2020-curriculum-vitae.pdf

Mirsapasi, N., \& Qahramani, M. (2011). The necessity of adapting the approach of fundamental change (macro implementation and based on systemic attitude) to the transformation plan in the administrative system of the Iranto improve and enhance the capability and capability of the government. Quarterly Journal of Management Research. 22(88), 1-22. https://www.sid.ir/fa/Journal/ViewPaper.aspx?id=144889

Mohammadi, M., \& Sharifzadeh, F. (2017). Designing a performance management model with a human resource development approach in the public sector. Quarterly Journal of Human $\begin{array}{lllll}\text { Resources Education } \quad \text { and } & \text { 133-159. }\end{array}$ https://www.sid.ir/fa/journal/ViewPaper.aspx?id=361410

Mohammadi, M., Alwani, S.M., \& Memarzadeh, G. (2016). Designing a governance model for the implementation of human resource policies in the Iranian government (Case study: Civil Service Management Rule). Quarterly Journal of Management of Government Organizations, 4(2), 13-30. http://ipom.journals.pnu.ac.ir/article_2743.html

Nadler, D. A. \& Tushman, M. L. (2006). A Model for Diagnosing Organizational Behavior. Organizational Dynamics, $\quad 9(2), \quad$ 35-51. https://www.hbs.edu/faculty/Pages/item.aspx?num=2974

Najabatkhah, M., \& Faqih Larijani, F. (2016). A reflection on the jurisdiction of the Court of Administrative Justice to hear claims arising from employment contracts. Journal of Public Rule Studies, 46(2), 231-245. https://jplsq.ut.ac.ir/article_58195.html

Porras, J.I., \& Berg, P.O. (2008). The Impact of Organization Development. Academy of Management Review, 3, 249-266. https://journals.sagepub.com/doi/10.1177/0021886394303003

Purkiani, M., Salajeqeh, S., \& Fezollah Z. (2014). Explaining barriers to policy implementation using centralized group discussion (Case study: Civil Service Management Rule). Quarterly Journal of Management of Government Organizations. 30(9), 78-90. https://www.sid.ir/fa/journal/ViewPaper.aspx?id=140544 
Qitani, A., Memarzadeh, Gh., \& Mirsapasi, N. (2017). Designing a human resource management model with a socio-technical and ecological approach for the Iranian public sector. Public Management Perspectives, 30, 74-57. http://jpap.sbu.ac.ir/article/view/22689

Ronaq, Y. (2009). Civil Service Management Rule regulating the relationship between government, people and employees. Journal of Human Resources, 2, 23-41. https://hrmj.ihu.ac.ir/

Rostami, V. (2010). Legal review of entry into service and employment in the Civil Service Management Rule (Chapters 7 and 8). Critical Journal of Texts and Programs of Humanities, Institute of Humanities and Cultural Studies, 10(2), 125-150. http://ensani.ir/fa/article/272491

Salehi, S., Daneshfard, K., Mirsapasi, N., \& Goodarzvand, M. (2018). Model of human resources supply and adjustment system (research in the Civil Service Management Rule). Quarterly Journal of Human Resource Management Research, Imam Hossein University, 10 (2), 75100. https://hrmj.ihu.ac.ir/article_32464_d53bba827fd76a865f284e4e02631d94.pdf

Shahlaei, N. (2017). Problems and obstacles of the legal system and benefits of the armed forces. Defense Strategy Quarterly, 15(59), 1-30. https://ds.sndu.ac.ir/article_104.html

Shum, C., Gatling, A., \& Shoemaker, S. (2018). A model of hospitality leadership competency for frontline and director-level managers: Which competencies matter more? International Journal of Hospitality Management, 74, 57-66. 10.1016/j.ijhm.2018.03.002

Singe, P. (2008). Fifth Commandment: Creating a Learning Organization. Translated by Hafez Kamal Hedayat and Mohammad Roshan. Tehran: Industrial Management Organization Publications, Tehran. http://journal.cesir.ir/article_106850_09232b5ff1961ed5b2a5e901b72e289c.pdf 